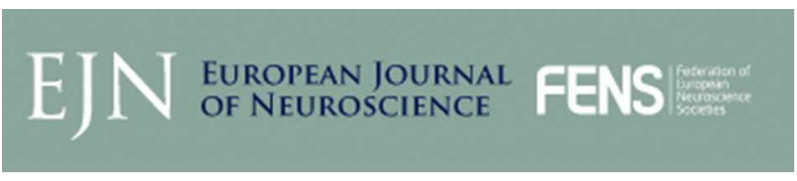

\title{
GABAB modulation of dopamine release in the Nucleus Accumbens core
}

\begin{tabular}{|r|l|}
\hline Journal: & European Journal of Neuroscience \\
\hline Manuscript ID: & EJN-2014-07-21927(R) \\
\hline Danuscript Type: & Research Report \\
\hline Complete List of Authors: & $\begin{array}{l}\text { Pitman, Kimberley; University of British Columbia, Anesthesiology, } \\
\text { Pharmacology and Therapeutics } \\
\text { Puil, Ernest; University of British Columbia, Anesthesiology, Pharmacology } \\
\text { and Therapeutics } \\
\text { Borgland, Stephanie; University of Calgary, Department of Physiology \& } \\
\text { Pharmacology }\end{array}$ \\
\hline Key Words: & $\begin{array}{l}\text { Brain Reward system, dopamine, Drugs of Abuse, GABAB receptors, } \\
\text { nucleus accumbens }\end{array}$ \\
\hline
\end{tabular}

\section{SCHOLARONE ${ }^{m}$ \\ Manuscripts}

This is the pre-peer reviewed version of the following article: [GABAB modulation of dopamine release in the Nucleus Accumbens core] which has been published in final form at [http://dx.doi.org/10.1111/ejn.12733]. This article may be used for non-commercial purposes in accordance with Wiley Terms and Conditions for Use of Self-Archived Versions 


\section{$\mathrm{GABA}_{\mathrm{B}}$ modulation of dopamine release in the Nucleus Accumbens core}

Kimberley A. Pitman, B.Sc. ${ }^{1,2}$, Ernest Puil, Ph.D ${ }^{1}$, Stephanie L. Borgland, Ph.D., ${ }^{2,3}$

${ }^{1}$ Department of Anesthesiology, Pharmacology \& Therapeutics

University of British Columbia

2176 Health Sciences Mall

Vancouver, BC V6T 1 Z3

${ }^{2}$ Hotchkiss Brain Institute

University of Calgary

3330 Hospital Dr. NW

Calgary, AB T2N 4N1

${ }^{3}$ To whom correspondence should be addressed

Tel: 403-220-6967

Fax: 403-283-2700

Email: s.borgland@ucalgary.ca

Running Title: $\mathrm{GABA}_{\mathrm{B}}$ modulation of dopamine release

Number of pages: 30, number of figures: 6

Word count: Whole manuscript; 7276, Abstract; 246, Introduction; 466

Keywords: Baclofen, dopamine, voltammetry, C57 B1/6J mice, cocaine 


\begin{abstract}
Modulation of the concentration of dopamine released from dopaminergic terminals in the nucleus accumbens (NAc) influences behaviours such as the motivation to obtain drugs of abuse. $\gamma$-aminobutyric acid type $\mathrm{B}\left(\mathrm{GABA}_{\mathrm{B}}\right)$ receptors are expressed throughout the mesolimbic circuit, including in the NAc, and baclofen, an agonist of $\mathrm{GABA}_{\mathrm{B}}$ receptors, can decrease drug-seeking behaviours. However, the mechanism by which $\mathrm{GABA}_{\mathrm{B}}$ receptors modulate terminal dopamine release has not been well studied. We explored how baclofen modulates the concentration of dopamine released from terminals in the NAc core using fast scan cyclic voltammetry in brain slices from adult male C57 Bl/6J mice. We found that baclofen concentration-dependently decreased single pulse evoked dopamine release. This effect was blocked by the GABA antagonist, CGP 52432, but not by a nicotinic acetylcholine receptor antagonist. Suppression of dopamine release by a saturating concentration of baclofen was sustained for up to an hour. The effect of baclofen was reduced with electrical stimulations mimicking burst firing of dopamine neurons. Similar to the $\mathrm{D}_{2}$ receptor agonist, quinpirole, baclofen reduced the probability of dopamine release, supporting a mechanistic overlap with $\mathrm{D}_{2}$ receptors. Baclofen-mediated suppression of dopamine release persisted after a locomotor sensitising cocaine treatment indicating that $\mathrm{GABA}_{\mathrm{B}}$ receptors on dopamine terminals were not altered by cocaine exposure. These data suggest that baclofen-mediated suppression of terminal dopamine release is due to $\mathrm{GABA}_{\mathrm{B}}$ activation on dopamine terminals to reduce the probability of dopamine release. This effect does not readily desensitize and persists regardless of chronic cocaine treatment.
\end{abstract}




\section{Introduction}

A critical part of the neural circuitry mediating motivated behaviours comprises ventral tegmental area (VTA) dopamine (DA) neurons and their projections to the nucleus accumbens (NAc). A change in the firing pattern of VTA DA neurons from tonic to burst firing results in increased DA release (Zhang et al., 2009a). Goal-directed behaviours are coupled to phasic increases in the concentration of DA released from terminals (Gan et al., 2010; Sugam et al., 2012). Therefore, factors that influence extracellular DA concentration ([DA $\left.]_{\mathrm{o}}\right)$ in the NAc play an important role in shaping behaviour.

In addition to reuptake via DA transporters which are highly expressed in the NAc (Nirenberg et al., 1997), there are several mechanisms regulating $[\mathrm{DA}]_{\mathrm{o}}$. Acetylcholine (ACh) from cholinergic interneurons enhances release of DA by activating nicotinic ACh receptors on dopaminergic nerve terminals (Zhou et al., 2001). Conversely, inhibition of DA release can occur by activation of presynaptic $\mathrm{D}_{2}$ DA receptors (Schmitz et al., 2002) or kappa-opioid receptors (Britt \& McGehee, 2008) located on DA nerve terminals. Mu-opioid receptors are expressed on cholinergic interneurons and decrease $[\mathrm{DA}]_{\mathrm{o}}$ by inhibiting ACh release (Britt \& McGehee, 2008). During a pulse train stimulation, activation of ionotropic glutamate $\alpha$-amino-3hydroxy-5-methyl-4-isoxazolepropionic acid (AMPA) receptors on medium spiny neurons inhibits DA release via retrograde action of $\mathrm{H}_{2} \mathrm{O}_{2}$ at DA terminals, whereas, activation of ionotropic $\gamma$-aminobutyric acid (GABA) receptors on medium spiny neurons opposes this effect (Avshalumov et al., 2003). Interestingly, inhibition of AMPA or $\mathrm{GABA}_{\mathrm{A}}$ receptors does not modulate single-pulse evoked [DA $]_{\mathrm{o}}$ in striatal slices (Chen et al., 2006), making this an ideal preparation for exploring the direct modulation of terminal DA release (Zhang \& Sulzer, 2012; Ferris et al., 2013). 
G-protein coupled GABA type $B\left(\mathrm{GABA}_{\mathrm{B}}\right)$ receptors are expressed in both the VTA and the NAc (Bowery et al., 1987; Ciccarelli et al., 2012). While the effects of activation of GABA receptors on DA cell bodies in the VTA are well characterised (Johnson \& North, 1992; Cruz et al., 2004), the role that $\mathrm{NAc} \mathrm{GABA}_{\mathrm{B}}$ receptors have in modulating terminal dopamine release requires further investigation. In vivo studies have demonstrated that reverse dialysis of baclofen, a $\mathrm{GABA}_{\mathrm{B}}$ receptor agonist, in the NAc decreases DA release (Xi et al., 2003). However, it is unknown if this is due to a direct effect on DA neuron nerve terminals. Therefore, we measured electrically stimulated DA release in ventral striatal slices using fast scan cyclic voltammetry.

Several studies demonstrate that baclofen can reduce drug seeking behaviours in humans and rodent models of addiction (Shoptaw et al., 2003; Slattery et al., 2005; Halbout et al., 2011). One consideration for the pharmacological treatment of drug addiction is whether drugs of abuse can alter the effectiveness of therapeutic agents such as baclofen. Therefore, we also tested if $\mathrm{GABA}_{\mathrm{B}}$-mediated alterations in DA release were modulated by chronic cocaine exposure.

\section{Materials and Methods}

Subjects

Male C57BL/6 mice (2-3 months, 47 animals total), provided by the University of British Columbia breeding facility or Jackson Laboratory (Sacremento, CA), were maintained on a 12 hour light dark cycle ( $7 \mathrm{am}-7 \mathrm{pm})$ with access to food and water ad libitum. Male mice were used to exclude cyclic effects of estradiol and progesterone on DA concentration (Becker, 1999). All experiments were performed in the light cycle. All experiments were carried out in accordance with the Canadian Council on Animal Care for protection of animals used for 
scientific purposes and directly approved by institutional committees (University of British Columbia Animal Care Committee and University of Calgary Health Sciences Animal Care Committee) enforcing these guidelines.

Slice Preparation

Mice were anaesthetised with isoflurane, decapitated and the brain tissue extracted into ice-cold sucrose solution containing (in mM) sucrose (75), $\mathrm{NaCl}$ (87), $\mathrm{KCl}$ (2.5), $\mathrm{NaH}_{2} \mathrm{PO}_{4}$ (1.25), $\mathrm{NaHCO}_{3}(25), \mathrm{MgCl}_{2}$ (7) and $\mathrm{CaCl}_{2}$ (0.95). Coronal slices containing the NAc core were cut $250 \mu \mathrm{m}$ thick using a vibratome (Leica, Nussloch, Germany). Slices were incubated in artificial cerebral spinal fluid (ACSF) containing (in mM) $\mathrm{NaCl}$ (119), $\mathrm{KCl}$ (1.6), $\mathrm{NaH}_{2} \mathrm{PO}_{4}(1.0)$. $\mathrm{NaHCO}_{3}$ (26.2), $\mathrm{MgCl}_{2}$ (1.4), $\mathrm{CaCl}_{2}$ (2.4) and glucose (11) at $31.5^{\circ} \mathrm{C}$ for at least 45 minutes before being transferred to a bath constantly perfused $(1.67 \mathrm{~mL} / \mathrm{min})$ with the same ACSF at $31.5^{\circ} \mathrm{C}$ for voltammetry recordings. All solutions were continuously saturated with $95 \% \mathrm{O}_{2} / 5 \%$ $\mathrm{CO}_{2}$.

\section{Cocaine administration}

Mice (2 months, 22 - 30 g) were divided into groups and habituated to locomotor activity boxes for 30 minutes. The following day (day 0) all groups were given a single $0.9 \%$ saline injection $(10 \mu \mathrm{L} / \mathrm{g})$. For the next 5 days mice were given either daily i.p. injections of $15 \mathrm{mg} / \mathrm{kg}$ cocaine $\mathrm{HCl}$ or the equivalent volume of saline. Locomotor activity was recorded for 30 minutes each day immediately after the injection using ANY-maze software V 4.81 (Stoelting, Wood 
Dale, Illinois). Slices were prepared for voltammetry either 24 hours or $10-12$ days after the final injection.

Fast-Scan Cyclic Voltammetry

DA release in the NAc core was measured using fast scan cyclic voltammetry. DA release was evoked using electrical stimulation applied with a bipolar stimulating electrode positioned flush with the tissue for local surface stimulation. The electrical stimulation was either a single monophasic rectangular pulse ( $2 \mathrm{~ms}$ duration, $8 \mathrm{~V}$ amplitude, $300 \mu \mathrm{A}$ current) or the same pulse applied 2 or 5 times at varying frequencies $(10,40$ or $100 \mathrm{~Hz})$. The higher frequency stimulations were designed to mimic burst firing of DA neurons (Rice \& Cragg, 2004; Zhang \& Sulzer, 2004; Ferris et al., 2013). Carbon fibre microelectrodes (tip length of 150 - $180 \mu \mathrm{m}$ ) were prepared by pulling glass electrodes containing $7 \mu \mathrm{m}$ diameter carbon fibres (Goodfellow, Coraopolis, Pennsylvania, USA). The voltammetric electrode was positioned between the tips of the stimulating electrode with the aid of a binocular microscope and then lowered $50-100 \mu \mathrm{m}$ into the tissue. A triangular waveform (from -0.4 to $+1.0 \mathrm{~V}$ vs. $\mathrm{Ag} / \mathrm{AgCl}, 400 \mathrm{~V} / \mathrm{s}$ scan rate) was applied at $10 \mathrm{~Hz}$ to induce the oxidation and reduction of DA at the surface of the carbon fibre electrode. The evoked currents were attributed to DA when the corresponding voltammogram featured a characteristic shape with peak oxidation and reduction potentials (vs. $\mathrm{Ag} / \mathrm{AgCl})$ at approximately +600 and $-200 \mathrm{mV}$, respectively. To determine the time course of DA release and uptake, the current at the peak oxidation $(\sim+600 \mathrm{mV})$ was plotted against time. Carbon fibre electrodes were calibrated post hoc using ACSF containing $1 \mu \mathrm{M}$ DA. Recordings were made every 5 minutes unless otherwise stated. Once a stable baseline for peak DA release had been 
achieved (4 consecutive recordings within $10 \%$ of each other) drugs were bath applied for 10 or $60 \mathrm{~min}$. The time point of 10 minutes was chosen based on electrophysiological studies in slices in which the maximum effect of baclofen occurred within 5 minutes (Cruz et al., 2004; Cooke et al., 2012). For paired pulse experiments, DA release was electrically evoked every 2.5 min alternating between a single pulse (P1) or 2 pulses $10 \mathrm{~ms}$ apart; (P1+P2 at $100 \mathrm{~Hz}, \mathrm{Cragg}, 2003$; Zhang and Sulzer, 2004). Once the peak values for both $\mathrm{P} 1$ and $\mathrm{P} 1+\mathrm{P} 2$ had stabilised, the current elicited by $\mathrm{P} 1$ was subtracted from the current elicited during P1+P2 to determine the current attributable to $\mathrm{P} 2$ (i.e., $\mathrm{P} 1+\mathrm{P} 2-\mathrm{P} 1=\mathrm{P} 2$ ). The paired pulse ratio was reported here as $\mathrm{P} 2 / \mathrm{P} 1$.

\section{Drugs}

Stock solutions of R-baclofen HCl (Sigma, Oakville, Ontario, Canada) and CGP 52432 (Tocris, Minneapolis, Minnesota, USA) were made with double distilled $\mathrm{H}_{2} \mathrm{O}$ and stored at $4{ }^{\circ} \mathrm{C}$. Quinpirole $\mathrm{HCl}$ (Tocris) and mecamylamine $\mathrm{HCl}$ (Sigma) stock solutions were prepared with double distilled $\mathrm{H}_{2} \mathrm{O}$ then aliquoted and frozen. DA (3-hydroxytyramine-HCl, Sigma) stock was made up with Na-metabisulfite (Fisher, Ottawa, Ontario, Canada) daily. Drugs were made to their final concentration in oxygenated ACSF on the day of experimentation. Cocaine $\mathrm{HCl}$ (Sigma) was made to a final concentration with $0.9 \%$ saline and stored at $4{ }^{\circ} \mathrm{C}$ for no longer than a week.

\section{Statistical analysis}


Peak baseline DA release for each slice was determined by averaging the peak current of the 4 consecutive recordings before drug application. All recordings were then expressed as a percentage of the baseline value. To assess changes in DA reuptake rate, a $1.5 \mathrm{~s}$ section of current vs. time was plotted from $0.2 \mathrm{~s}$ after the peak and the time constant (tau) of the decay was measured using GraphPad Prism V. 5 (La Jolla, California, USA). To determine the maximal uptake rate $\left(\mathrm{V}_{\max }\right)$ we used the equation $\mathrm{d}[\mathrm{DA}] / \mathrm{dt}=-\mathrm{Vmax} /((\mathrm{Km} /[\mathrm{DA}])+1)$ where $\mathrm{Km}$ has been experimentally determined to be $0.2 \mu \mathrm{M}$ and d[DA]/dt was measured as the slope of the initial (linear) portion of the DA decay curve between points where the concentration of DA released was equivalent for baseline and baclofen treatment (Near et al., 1988; Wightman et al., 1988; Wightman \& Zimmerman, 1990). For electrochemistry experiments, "n" refers to the number of recordings (maximum one per slice) from at least three mice, expressed as number of recordings/number of mice. A power analysis indicates that to detect a minimum $10 \%$ change in effect with a statistical power level of 0.8 , we required a sample size of at least four slices per group. Unless otherwise indicated, data met the assumptions of equal variances. Final data is expressed as mean \pm SEM between recordings or for the locomotor activity data between animals. Paired or unpaired t-tests and one or two-way ANOVAs with Bonferroni's post-hoc test were performed as appropriate using GraphPad Prism V. 5. A p value of $<0.05$ was considered statistically significant.

\section{Results}

Activation of $G A B A_{B}$ receptors inhibits DA release in the NAc core 
To determine if baclofen could modify $[\mathrm{DA}]_{\mathrm{o}}$, baclofen was bath applied to ventral striatal slices that contained the NAc core. Baclofen $(100 \mu \mathrm{M} ; 10 \mathrm{~min})$ reduced single-pulse evoked $[\mathrm{DA}]_{\mathrm{o}}$ to $76 \pm 4 \%$ of baseline, an effect that was completely washed out after $30 \mathrm{~min}$ (baseline: $100 \pm 0.9 \%$, wash: $102 \pm 2 \% \mathrm{p}<0.001$, repeated measures one-way ANOVA, $\mathrm{F}_{(2,8)}=$ 23.02, $n=9 / 3$; Fig. 1A, B, D). Pre-treatment of the GABA B receptor antagonist, CGP 52432 (1 $\mu \mathrm{M} ; 10 \mathrm{~min}$ ) alone did not significantly alter $[\mathrm{DA}]_{\mathrm{o}}$ and blocked the baclofen-mediated suppression of $[\mathrm{DA}]_{\mathrm{o}}$ in the NAc core (baseline: $101 \pm 0.3 \%$, CGP 52432: $101 \pm 3 \%$, baclofen + CGP 5234: $98 \pm 2 \%, \mathrm{p}>0.05$, repeated measures one-way ANOVA, $\mathrm{F}_{(2,5)}=1.04, \mathrm{n}=6 / 3$; Fig. 1A, C). The effect of baclofen was concentration-dependent with an $\mathrm{IC}_{50}$ of $3.7 \pm 0.4 \mu \mathrm{M}$ (Fig. 1E). The data summarized in Fig. $1 \mathrm{~B}, \mathrm{C}$ suggest that baclofen acts at $\mathrm{GABA}_{\mathrm{B}}$ receptors to suppress $[\mathrm{DA}]_{\mathrm{o}}$. Further, single-pulse electrical stimulation does not evoke sufficient endogenous GABA release to modulate $\mathrm{GABA}_{\mathrm{B}}$ receptors.

Pharmacotherapy with baclofen likely requires sustained suppression of DA release. To assess if the effect of baclofen changed over time, we bath applied $100 \mu \mathrm{M}$ baclofen to slices for 60 min. Maximal baclofen-mediated suppression of single pulse-evoked [DA] $]_{\mathrm{o}}$ after 10 min application was not significantly different to baclofen-mediated suppression after 60 min application (baseline: $1.1 \pm 0.2 \mu \mathrm{M}$; baclofen $_{10 \mathrm{~min}}$ : $0.8 \pm 0.1 \mu \mathrm{M}$; baclofen $_{60 \text { min }}: 0.8 \pm 0.1 \mu \mathrm{M}, \mathrm{p}$ $>0.05$, repeated measure one way ANOVA, $\mathrm{F}_{(2,7)}=9.72, \mathrm{n}=8 / 3$; Fig. $\left.2 \mathrm{~A}, \mathrm{~B}, \mathrm{C}\right)$, indicating that prolonged application of a saturating baclofen concentration maintains its efficacy at suppressing $[\mathrm{DA}]_{\mathrm{o}}$

Next, we assessed if baclofen-mediated suppression of $[\mathrm{DA}]_{\mathrm{o}}$ was due to a reduction in DA release, or an increase in DA reuptake. The time constant of the decay of the current, 
represented by Tau $(\tau)$, has been demonstrated to be positively correlated with $\mathrm{K}_{\mathrm{m}}$, suggesting that $\tau$ is an appropriate measurement of DA uptake (Yorgason et al., 2011). Current vs. time plots of evoked DA indicated that baclofen (10 or $60 \mathrm{~min})$ did not significantly alter the decay of the current $\left(\tau_{\text {baseline }}=0.2 \pm 0.02 \mathrm{~s}, \tau_{\text {baclofen }} 10 \mathrm{~min}=0.2 \pm 0.02 \mathrm{~s} ; \tau_{\text {baclofen }} 60 \min =0.2 \pm 0.01 \mathrm{~s} ; \mathrm{p}>\right.$ 0.05 , repeated measures one-way ANOVA, $\mathrm{F}_{(2,7)}=0.19, \mathrm{n}=8 / 3$; Fig. 2D). Furthermore, $\mathrm{V}_{\max }$ was not significantly changed in the presence of baclofen (baseline: $2.2 \pm 0.1 \mu \mathrm{M} / \mathrm{min}$, baclofen $_{10 \min }: 2.1 \pm 0.1 \mu \mathrm{M} / \mathrm{min}$; baclofen $_{60 \mathrm{~min}}: 2.0 \pm 0.2 \mu \mathrm{M} / \mathrm{min} ; \mathrm{P}>0.05$, repeated measures one-way ANOVA, $\left.\mathrm{F}_{(2,7)}=1.34, \mathrm{n}=8 / 3\right)$.

Previous studies have found that antagonists for glutamate, GABA, adenosine, opioid and cannabinoid receptors have no effect on single-pulse evoked DA release (Zhang \& Sulzer, 2012). However, the electrical stimulation used to evoke DA release in the ventral striatum also evokes ACh release that enhances DA release via a rapid action at nicotinic ACh receptors (Zhou et al., 2001). Thus, baclofen-mediated suppression of DA release may be indirect, due to an effect of $\mathrm{GABA}_{\mathrm{B}}$ receptors on cholinergic interneurons in the NAc. If this hypothesis is correct, the effect of baclofen should be occluded by preventing ACh action on nicotinic ACh receptors. We blocked nicotinic ACh receptors by bath applying mecamylamine $(100 \mu \mathrm{M})$ for 30 minutes, resulting in an inhibition of single-pulse evoked DA release to $50 \pm 5 \%$ of baseline (Fig. 3A). Subsequently, in the presence of mecamylamine, baclofen $(100 \mu \mathrm{M})$ was bath applied for 10 minutes. Analysis with a two-way ANOVA revealed no effect of mecamylamine on baclofenmediated suppression of DA release (baclofen: $78 \pm 1 \%$ of baseline, $n=7 / 3$; baclofen and mecamylamine: $86 \pm 3 \%$ of baseline, $\mathrm{n}=7 / 3 ; \mathrm{p}>0.05$, repeated measures two-way ANOVA, $\mathrm{F}_{(1,12)}=2.06$; Fig. 3A,B).

Baclofen-mediated suppression of DA release is frequency-dependent 
To assess the frequency-dependence of baclofen-mediated suppression of $[\mathrm{DA}]_{\mathrm{o}}$, we tested the effect of baclofen on DA release evoked with 5 pulses at 10, 40 or $100 \mathrm{~Hz}$. Interestingly, baclofen-mediated suppression was inversely proportional to the frequency at which DA release was evoked. At $10 \mathrm{~Hz}$, baclofen $(100 \mu \mathrm{M}, 10 \mathrm{~min})$ inhibited [DA] to $69 \pm 12$ $\%$ of baseline $(n=9 / 3)$, which was significantly different from the magnitude of baclofenmediated inhibition at $100 \mathrm{~Hz}\left(90 \pm 4 \%\right.$ of baseline, $\mathrm{n}=9 / 4, \mathrm{p}<0.001$, one way ANOVA, $\mathrm{F}_{(2,24)}$ $=13.59$, Fig 4A, B, C). The inhibitory effect of baclofen on DA evoked at $40 \mathrm{~Hz}$ (cf. Fig. 4C) was blocked with CGP $52432(1 \mu \mathrm{M}, 10 \mathrm{~min})$ (baseline: $100 \pm 1 \%$, CGP 52432: $101 \pm 5 \%$, baclofen + CGP 52432: $101 \pm 4 \%, \mathrm{n}=9 / 3, \mathrm{P}>0.05$, repeated measures one-way ANOVA, $\mathrm{F}_{(2,8)}$ $=0.233)$.

To further explore the mechanism by which baclofen inhibits $[\mathrm{DA}]_{\mathrm{o}}$, we investigated if baclofen alters the probability of DA release. Short-term plasticity occurs by altering calcium entry or hyperpolarising nerve terminals resulting in residual $\mathrm{Ca}^{2+}$, which then promotes neurotransmitter release to subsequent stimulations in close succession (Cragg, 2003; Zhang \& Sulzer, 2004, 2012). Interventions that decrease the probability of neurotransmitter release produce a higher paired pulse ratio of neurotransmitter release (Cragg, 2003; Zhang \& Sulzer, 2004, 2012). We measured the effect of baclofen on the paired pulse ratio using a protocol described in Cragg, 2003 and Zhang \& Sulzer, 2004. A single pulse stimulation (termed P1) was followed 2.5 minutes later by a two pulse stimulation with an interpulse interval of $10 \mathrm{~ms}$ (P1+P2), which can occur during DA neuron burst firing (Hyland et al., 2002). The current attributable to the second pulse of the two pulse stimulus (P2) was determined by subtracting the current elicited by the single pulse stimulus from the current elicited by the two pulse stimulation 
(i.e., $\mathrm{P} 1+\mathrm{P} 2$ - $\mathrm{P} 1=\mathrm{P} 2)$. The magnitude of $\mathrm{P} 2$ was then expressed as a fraction of $\mathrm{P} 1$ (P2/P1, i.e., the paired pulse ratio).

Consistent with previous work (Zhang \& Sulzer, 2004), we observed a basal paired-pulse depression of DA release (Fig. 5). However, after baclofen application (100 $\mu \mathrm{M})$, the pairedpulse ratio was significantly increased (baseline $\mathrm{P} 2 / \mathrm{P} 1$ : $0.6 \pm 0.1$ vs. baclofen $\mathrm{P} 2 / \mathrm{P} 1$ : $0.8 \pm 0.1, \mathrm{p}$ $<0.01$, paired t-test, $\mathrm{t}=3.51, \mathrm{df}=10, \mathrm{n}=11 / 4$; Fig. 5B, D). Consistent with a decrease in release probability, application of quinpirole $(300 \mathrm{nM})$, which activates $\mathrm{D}_{2}$ presynaptic autoreceptors to inhibit evoked DA release (Schmitz et al, 2003), increased the paired-pulse ratio (baseline P2/P1: $0.5 \pm 0.07$ vs. quinpirole $\mathrm{P} 2 / \mathrm{P} 1: 1 \pm 0.1, \mathrm{p}<0.05$, paired t-test, $\mathrm{t}=3.58$, df $=6$, $n=7 / 3$; Fig. 5C, D). Notably, DA release at P1 was significantly less with quinpirole than baclofen (quinpirole ${ }_{10 \min }: 32 \pm 6 \%$ of baseline vs. baclofen $_{10 \min }: 75 \pm 4 \%$ of baseline, $\mathrm{p}<0.001$, two way ANOVA with bonferroni post hoc $\mathrm{F}_{(8,141)}=8.95$, Fig. 5A).

\section{Baclofen-induced suppression of DA release persists in cocaine-sensitized mice}

Baclofen has been tested as a therapeutic agent for cocaine addiction (Shoptaw et al., 2003). Therefore, we determined if chronic cocaine treatment altered baclofen-mediated suppression of DA release. As shown in Figure 6A, locomotor activity in mice immediately following cocaine administration $(15 \mathrm{mg} / \mathrm{kg}$, i.p.) was significantly greater after 5 daily injections compared to the first day (distance travelled day 1: $147 \pm 13 \mathrm{~m}$ vs. day 5: $218 \pm 25 \mathrm{~m}$, $\mathrm{p}<0.05$, one way ANOVA, $\left.\mathrm{F}_{(2,15)}=28.49, \mathrm{n}=6\right)$, demonstrating that these mice exhibited locomotor sensitisation to cocaine. In slices containing the NAc core taken 24 hours after the final cocaine injection, baclofen $(100 \mu \mathrm{M}, 10 \mathrm{~min})$ inhibited single pulse-evoked DA release to 
$78 \pm 4 \%(\mathrm{n}=7 / 3)$ of baseline while the suppression of DA release in slices from saline injected mice was $79 \pm 7 \%$ of baseline $(n=4 / 3$; Fig, $6 B, C)$. Baclofen-mediated suppression of $[\mathrm{DA}]_{\mathrm{o}}$ was similar after 10 - 12 days withdrawal from cocaine or saline (cocaine: $74 \pm 5 \%$ of baseline $(n=6 / 3)$ vs. saline: $76 \pm 4 \%$ of baseline $(n=6 / 3)$, Fig. 6B, C). Analysis with two-way ANOVA showed no effect of cocaine treatment $\left(\mathrm{F}_{(1,19)}=0.44, \mathrm{p}>0.05\right)$ or withdrawal period $\left(\mathrm{F}_{(1,19)}=\right.$ 0.02, $\mathrm{p}>0.05)$. To determine if evoked GABA could alter $\mathrm{GABA}_{\mathrm{B}}$-mediated suppression of DA after withdrawal from cocaine treatment, we bath applied a $\mathrm{GABA}_{\mathrm{B}}$ antagonist to slices taken from mice 10-12 days after the final cocaine injection. CGP $52432(1 \mu \mathrm{M}, 10$ or $30 \mathrm{~min})$ did not significantly alter evoked [DA] $]_{\mathrm{o}}$ (baseline: $99 \pm 1 \%$, CGP 52432 $10 \mathrm{~min}: 101 \pm 2 \%$, CGP 52432 30 $\min : 98 \pm 4 \%$, repeated measures one-way ANOVA, $F_{(2,3)}=0.14, n=4 / 3$; Fig. 6D, E) suggesting withdrawal from chronic cocaine treatment does not increase endogenous GABA tone at GABA receptors on DA terminals in slices. Taken together, these results suggest that baclofen-mediated suppression of DA release persists with chronic cocaine treatment.

\section{Discussion}

We report here that baclofen acts at presynaptic $\mathrm{GABA}_{\mathrm{B}}$ receptors on DA neurons in the NAc core to reduce the probability of DA release. Furthermore, baclofen-mediated inhibition of DA release in the NAc was resistant to desensitization and was not altered by a sensitizing cocaine regimen. Because baclofen has been proposed as a potential therapeutic for anti-craving and the maintenance of abstinence in cocaine addicts (Tyacke et al., 2010), these data support the notion that $\mathrm{GABA}_{\mathrm{B}}$ receptors are promising targets for addiction treatments. 
Activation of $G A B A_{B}$ on DA terminals suppresses DA release in the NAc core

Our data support the hypothesis that baclofen acts at $\mathrm{GABA}_{\mathrm{B}}$ receptors directly on DA terminals to inhibit DA release. Firstly, baclofen concentration-dependently inhibited DA release via activation of $\mathrm{GABA}_{\mathrm{B}}$ receptors in the NAc core. These results are consistent with the ability of baclofen to inhibit extracellular striatal dopamine in vivo (Smolders et al., 1995) and evoked DA in the caudate putamen in mouse brain slices (Schmitz et al., 2002). GABAB agonists do not alter the membrane properties of medium spiny neurons in the NAc suggesting that they do not

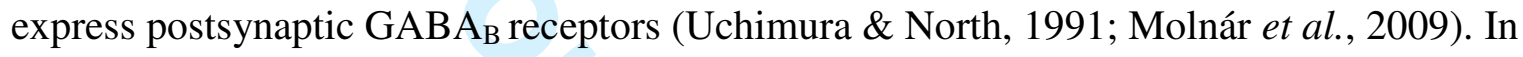
contrast, $\mathrm{GABA}_{\mathrm{B}}$ agonists can inhibit the release of GABA and glutamate onto medium spiny neurons, indicating that there are pre-synaptic $\mathrm{GABA}_{\mathrm{B}}$ auto- and hetero-receptors on the terminals of GABAergic and glutamatergic neurons (Uchimura \& North, 1991; Molnár et al., 2009). Because there is almost no tonic activity of amino-acid transmitters such as glutamate and GABA when DA release is evoked with a single pulse in slices (Chen et al., 2006; Zhang \& Sulzer, 2012), this preparation is an ideal way to determine whether drugs are able to act directly on DA terminals. In agreement with other literature using fast scan cyclic voltammetry in striatal brain slices (Chen et al., 2006), a single pulse stimulus was not sufficient to evoke endogenous GABA to act at $\mathrm{GABA}_{\mathrm{B}}$ receptors, as a $\mathrm{GABA}_{\mathrm{B}}$ antagonist alone had no effect on terminal DA release.

Secondly, baclofen continued to suppress DA release in the presence of a nicotinic ACh receptor antagonist. Tonically active cholinergic interneurons in the striatum contribute to increased $[\mathrm{DA}]_{\mathrm{o}}$ (Zhou et al., 2001). Our results support the hypothesis that baclofen does not act at these cholinergic interneurons to reduce electrically evoked DA release by inhibiting ACh 
release. This is consistent with in vivo microdialysis studies that demonstrate minimal effects of baclofen on ACh release in the NAc (Anderson et al., 1993; DeBoer \& Westerink, 1994).

Thirdly, similar to the $\mathrm{D}_{2}$ agonist quinpirole, baclofen reduces the probability of DA release, suggesting a mechanistic overlap. Both $\mathrm{D}_{2}$ receptors and $\mathrm{GABA}_{\mathrm{B}}$ receptors couple to $\mathrm{G}_{\text {ai/o }}$ proteins, inhibit voltage-gated calcium channels, and open G-protein coupled inwardly rectifying $\mathrm{K}^{+}$channels (Cardozo \& Bean, 1995; Beckstead et al., 2004; Cruz et al., 2004). Presynaptic $\mathrm{GABA}_{\mathrm{B}}$ receptors can inhibit neurotransmitter release by a rapid inhibitory effect on voltage-gated calcium entry into nerve terminals (Cardozo \& Bean, 1995; Laviv et al., 2011). Notably, the magnitude of paired pulse facilitation induced by baclofen was less than that induced by quinpirole. Because the paired pulse ratio is dependent on the release probability of the first pulse (Zhang et al., 2009b), the difference observed is likely due to the efficacy of quinpirole at inhibiting single pulse-evoked DA release compared to baclofen. A direct effect of $\mathrm{GABA}_{\mathrm{B}}$ receptor activation on DA release is supported by ultrastructural evidence of $\mathrm{GABA}_{\mathrm{B}}$ receptors expressed on DA terminals (Charara et al., 2000), which is presumably similar between monkeys and rodents.

Baclofen-mediated suppression of DA release is frequency-dependent

Midbrain DA neurons fire in a slow irregular fashion resulting in tonic release of DA. However, in response to salient environmental stimuli, spikes of DA neurons are clustered into bursts and the increase in $[\mathrm{DA}]_{\mathrm{o}}$ in the projection areas is much larger than that observed for regularly spaced trains of action potentials at the same frequency (Grace \& Bunney, 1984a, 1984b; Tepper et al., 1995; Overton \& Clark, 1997). Consistent with this idea, electrical 
stimulation mimicking burst firing increases [DA] $]_{\mathrm{o}}$ (Hyland et al., 2002; Zhang et al., 2009b; Ferris et al., 2013). Baclofen-mediated suppression of DA release was inversely proportional to the stimulation frequency, such that suppression of DA release evoked with a low frequency stimulus was significantly greater compared to suppression of DA evoked by burst stimuli. With a similar impact on tonic vs. burst firing to mu-opioids and nicotine (Zhang \& Sulzer, 2004; Britt \& McGehee, 2008), one might expect a modification in signal-to-noise ratio to enhance perception of important environmental stimuli (Couey et al., 2007; Zhang et al., 2009b). However, baclofen applied to the VTA decreases DA neuron activity in slices (Chen et al., 2005) and when given systemically, baclofen decreases the average firing rate and bursts of DA neurons in vivo (Erhardt et al., 2002). Therefore, because baclofen reduces DA burst firing and terminal DA release, the net effect of baclofen in the mesolimbic system is likely an overall suppression of DA outflow. Consistent with this, systemic baclofen decreases drug induced increases in DA concentration in the NAc measured with in vivo microdialysis (Fadda et al., 2003; Fu et al., 2012). Based on this, we speculate that baclofen reduces perception of salient stimuli, which may contribute to its role in reducing the reinforcing properties of addictive drugs (Vlachou \& Markou, 2010).

$G A B A_{B}$-mediated suppression of DA release persists with chronic cocaine treatment

A reduction in baclofen-mediated inhibition following cocaine exposure could have implications for the pharmacotherapy of addiction. Thus, it was of interest whether a sensitizing cocaine regimen induced changes in $\mathrm{GABA}_{\mathrm{B}}$ receptor-modulation of $\mathrm{DA}$ release at terminals in the NAc. Previous work has implicated increased GABAergic transmission in the NAc during 
cocaine self-administration (Wydra et al., 2013) or after withdrawal from chronic cocaine administration (Xi et al., 2003; Wydra et al., 2013). While it has been hypothesized that cocaineinduced increases in GABAergic transmission may alter $\mathrm{GABA}_{\mathrm{B}}$ receptor number or function (Xi et al., 2003), there is no consensus on whether $\mathrm{GABA}_{\mathrm{B}}$ receptors are altered with chronic cocaine treatment or withdrawal. For example, Frankowska et al., (2008) reported that GABA receptor binding was decreased immediately after chronic cocaine treatment and Xi et al. (2003) found that baclofen stimulated $\mathrm{GABA}_{\mathrm{B}}$ receptor activation was reduced after 3 weeks of withdrawal from chronic cocaine. However, another study reported that $\mathrm{GABA}_{\mathrm{B}}$ receptor activation was not altered immediately after chronic cocaine treatment (Kushner \& Unterwald, 2001). Our results demonstrate that $\mathrm{GABA}_{\mathrm{B}}$-mediated suppression of DA release was not altered 24h or 10-12 days after chronic cocaine treatment.

Discrepancies of previous findings may be due to the inability to establish whether the reduction in $\mathrm{GABA}_{\mathrm{B}}$ receptor binding/activation was ubiquitous among different neuronal inputs or cell populations within the NAc or due to changes at selective neuronal inputs. Using slice voltammetry, we were able to differentiate between $\mathrm{GABA}_{\mathrm{B}}$ activation on DA terminals as opposed to alterations of $\mathrm{GABA}_{\mathrm{B}}$ receptor function on glutamatergic or GABAergic terminals. Because a saturating dose of baclofen suppressed DA in the NAc to a similar extent in chronic cocaine or saline treated mice, it is unlikely that chronic cocaine treatment or withdrawal altered the number or function of $\mathrm{GABA}_{\mathrm{B}}$ receptors on dopamine terminals. Notably, while $\mathrm{Xi}$ et al. (2003) demonstrated that withdrawal from cocaine increased GABA in the NAc, there were no changes in basal DA or baclofen-induced inhibition of either glutamate or DA (Xi et al., 2003). These results suggest that while chronic cocaine may increase endogenous GABA, GABA uptake or degradation mechanisms may be sufficient to prevent GABA reaching concentrations 
which could produce agonist induced desensitisation of $\mathrm{GABA}_{\mathrm{B}}$ receptors on $\mathrm{DA}$ terminals, the mechanism hypothesised by Xi et al, (2003). Conversely, the mechanisms which result in desensitisation or down regulation of $\mathrm{GABA}_{\mathrm{B}}$ receptors may be less efficient at presynaptic $\mathrm{GABA}_{\mathrm{B}}$ receptors on DA neuron terminals. Indeed, our results support the latter hypothesis, because the response to prolonged application of a saturating concentration of baclofen did not desensitize, resulting in a sustained suppression of DA release.

Together these data suggest that baclofen inhibits DA release in the NAc core via action at $\mathrm{GABA}_{\mathrm{B}}$ receptors on DA terminals. Baclofen-mediated inhibition of DA release persisted with a sensitising cocaine treatment. Although drugs of abuse have different mechanisms of action, a common feature is that they all interact with the mesolimbic DA system to increase terminal DA concentration (Di Chiara \& Imperato, 1988). The magnitude of DA release in the NAc scales with the value of a reward or anticipated value of a forthcoming reward which helps shape reward-learning behaviour (Gan et al., 2010). The suppression of DA release in the NAc, regardless of cocaine treatment, suggests a potential mechanism for baclofen's utility as an anticraving compound. While the effect of baclofen was sustained for up to an hour in slices, in future studies it will be important to determine whether chronic systemic administration of baclofen alters the ability of baclofen to decrease terminal DA release as well as whether $\mathrm{GABA}_{\mathrm{B}}$ receptors are desensitised or down regulated inequitably on different dopaminergic, GABAergic or glutamatergic inputs to the NAc. 


\section{Acknowledgements}

This work was supported by an NSERC discovery grant and a CIHR new investigator award to S.L.B. The authors do not have any competing financial interests or potential conflicts. The authors wish to thank Dr. Bernard Macleod for their helpful suggestions on this project. 


\section{Abbreviations}

ACh: Acetylcholine

ACSF: $\quad$ Artificial cerebral spinal fluid

AMPA: $\quad \alpha$-amino-3-hydroxy-5-methyl-4-isoxazolepropionic acid

DA: Dopamine

GABA: $\quad \gamma$-aminobutyric acid

NAc: $\quad$ Nucleus accumbens

VTA: $\quad$ Ventral tegmental area

$[\mathrm{DA}]_{\mathrm{o}}: \quad$ Extracellular dopamine concentration 


\section{References}

Anderson, J.J., Kuo, S., Chase, T.N., \& Engber, T.M. (1993) GABAA and GABAB receptors differentially regulate striatal acetylcholine release in vivo. Neurosci. Lett., 160, 126-130.

Avshalumov, M. V, Chen, B.T., Marshall, S.P., Peña, D.M., \& Rice, M.E. (2003) Glutamatedependent inhibition of dopamine release in striatum is mediated by a new diffusible messenger, H2O2. J. Neurosci., 23, 2744-2750.

Becker, J.B. (1999) Gender differences in dopaminergic function in striatum and nucleus accumbens. Pharmacol. Biochem. Behav., 64, 803-812.

Beckstead, M.J., Grandy, D.K., Wickman, K., \& Williams, J.T. (2004) Vesicular dopamine release elicits an inhibitory postsynaptic current in midbrain dopamine neurons. Neuron, $\mathbf{4 2}$, 939-946.

Bowery, N.G., Hudson, A.L., \& Price, G.W. (1987) GABAA and GABAB receptor site distribution in the rat central nervous system. Neuroscience, 20, 365-383.

Britt, J.P. \& McGehee, D.S. (2008) Presynaptic opioid and nicotinic receptor modulation of dopamine overflow in the nucleus accumbens. J. Neurosci., 28, 1672-1681.

Cardozo, D.L. \& Bean, B.P. (1995) Voltage-dependent calcium channels in rat midbrain dopamine neurons: modulation by dopamine and GABAB receptors. J. Neurophysiol., 74, $1137-1148$. 
Charara, a, Heilman, T.C., Levey, a I., \& Smith, Y. (2000) Pre- and postsynaptic localization of GABA(B) receptors in the basal ganglia in monkeys. Neuroscience, 95, 127-140.

Chen, B.T., Moran, K. a, Avshalumov, M. V, \& Rice, M.E. (2006) Limited regulation of somatodendritic dopamine release by voltage-sensitive Ca channels contrasted with strong regulation of axonal dopamine release. J. Neurochem., 96, 645-655.

Chen, Y., Phillips, K., Minton, G., \& Sher, E. (2005) GABA(B) receptor modulators potentiate baclofen-induced depression of dopamine neuron activity in the rat ventral tegmental area. Br. J. Pharmacol., 144, 926-932.

Ciccarelli, A., Calza, A., Panzanelli, P., Concas, A., Giustetto, M., \& Sassoè-Pognetto, M. (2012) Organization of GABAergic synaptic circuits in the rat ventral tegmental area. PLoS One, 7, e46250.

Cooke, J.E., Mathers, D. a, \& Puil, E. (2012) R-Isovaline: a subtype-specific agonist at GABA(B)-receptors? Neuroscience, 201, 85-95.

Couey, J.J., Meredith, R.M., Spijker, S., Poorthuis, R.B., Smit, A.B., Brussaard, A.B., \& Mansvelder, H.D. (2007) Distributed network actions by nicotine increase the threshold for spike-timing-dependent plasticity in prefrontal cortex. Neuron, 54, 73-87.

Cragg, S.J. (2003) Variable dopamine release probability and short-term plasticity between functional domains of the primate striatum. J. Neurosci., 23, 4378-4385. 
Cruz, H.G., Ivanova, T., Lunn, M.-L., Stoffel, M., Slesinger, P. a, \& Lüscher, C. (2004) Bidirectional effects of GABA(B) receptor agonists on the mesolimbic dopamine system. Nat. Neurosci., 7, 153-159.

DeBoer, P. \& Westerink, B.H. (1994) GABAergic modulation of striatal cholinergic interneurons: an in vivo microdialysis study. J. Neurochem., 62, 70-75.

Di Chiara, G. \& Imperato, a (1988) Drugs abused by humans preferentially increase synaptic dopamine concentrations in the mesolimbic system of freely moving rats. Proc. Natl. Acad. Sci. U. S. A., 85, 5274-5278.

Erhardt, S., Mathé, J.M., Chergui, K., Engberg, G., \& Svensson, T.H. (2002) GABA(B) receptor-mediated modulation of the firing pattern of ventral tegmental area dopamine neurons in vivo. Naunyn. Schmiedebergs. Arch. Pharmacol., 365, 173-180.

Fadda, P., Scherma, M., Fresu, A., Collu, M., \& Fratta, W. (2003) Baclofen antagonizes nicotine-, cocaine-, and morphine-induced dopamine release in the nucleus accumbens of rat. Synapse, 50, 1-6.

Ferris, M.J., Calipari, E.S., Yorgason, J.T., \& Jones, S.R. (2013) Examining the complex regulation and drug-induced plasticity of dopamine release and uptake using voltammetry in brain slices. ACS Chem. Neurosci.,.

Fu, Z., Yang, H., Xiao, Y., Zhao, G., \& Huang, H. (2012) The $\gamma$-aminobutyric acid type B $(\mathrm{GAB} A \mathrm{~B})$ receptor agonist baclofen inhibits morphine sensitization by decreasing the dopamine level in rat nucleus accumbens. Behav. Brain Funct., 8, 20. 
Gan, J.O., Walton, M.E., \& Phillips, P.E.M. (2010) Dissociable cost and benefit encoding of future rewards by mesolimbic dopamine. Nat. Neurosci., 13, 25-27.

Grace, A.A. \& Bunney, B.S. (1984a) The control of firing pattern in nigral dopamine neurons: burst firing. J. Neurosci., 4, 2877-2890.

Grace, A.A. \& Bunney, B.S. (1984b) The control of firing pattern in nigral dopamine neurons: single spike firing. J. Neurosci., 4, 2866-2876.

Halbout, B., Quarta, D., Valerio, E., Heidbreder, C. a, \& Hutcheson, D.M. (2011) The GABA-B positive modulator GS39783 decreases psychostimulant conditioned-reinforcement and conditioned-reward. Addict. Biol., 16, 416-427.

Hyland, B.I., Reynolds, J.N.J., Hay, J., Perk, C.G., \& Miller, R. (2002) Firing modes of midbrain dopamine cells in the freely moving rat. Neuroscience, 114, 475-492.

Johnson, S.W. \& North, R.A. (1992) Two types of neurone in the rat ventral tegmental area and their synaptic inputs. J. Physiol., 450, 455-468.

Kushner, S.A. \& Unterwald, E.M. (2001) Chronic cocaine administration decreases the functional coupling of $\mathrm{GABA}(\mathrm{B})$ receptors in the rat ventral tegmental area as measured by baclofen-stimulated 35S-GTPgammaS binding. Life Sci., 69, 1093-1102.

Laviv, T., Vertkin, I., Berdichevsky, Y., Fogel, H., Riven, I., Bettler, B., Slesinger, P. a, \& Slutsky, I. (2011) Compartmentalization of the GABAB receptor signaling complex is required for presynaptic inhibition at hippocampal synapses. J. Neurosci., 31, 12523-12532. 
Molnár, T., Antal, K., Nyitrai, G., \& Emri, Z. (2009) gamma-Hydroxybutyrate (GHB) induces $\mathrm{GABA}(\mathrm{B})$ receptor independent intracellular $\mathrm{Ca} 2+$ transients in astrocytes, but has no effect on $\mathrm{GHB}$ or $\mathrm{GABA}(\mathrm{B})$ receptors of medium spiny neurons in the nucleus accumbens. Neuroscience, 162, 268-281.

Near, J.A., Bigelow, J.C., \& Wightman, R.M. (1988) Comparison of uptake of dopamine in rat striatal chopped tissue and synaptosomes. J. Pharmacol. Exp. Ther., 245, 921-927.

Nirenberg, M.J., Chan, J., Pohorille, a, Vaughan, R. a, Uhl, G.R., Kuhar, M.J., \& Pickel, V.M. (1997) The dopamine transporter: comparative ultrastructure of dopaminergic axons in limbic and motor compartments of the nucleus accumbens. J. Neurosci., 17, 6899-6907.

Overton, P.G. \& Clark, D. (1997) Burst firing in midbrain dopaminergic neurons. Brain Res. Brain Res. Rev., 25, 312-334.

Rice, M.E. \& Cragg, S.J. (2004) Nicotine amplifies reward-related dopamine signals in striatum. Nat. Neurosci., 7, 583-584.

Schmitz, Y., Benoit-Marand, M., Gonon, F., \& Sulzer, D. (2003) Presynaptic regulation of dopaminergic neurotransmission. J. Neurochem., 87, 273-289.

Schmitz, Y., Schmauss, C., \& Sulzer, D. (2002) Altered dopamine release and uptake kinetics in mice lacking D2 receptors. J. Neurosci., 22, 8002-8009.

Shoptaw, S., Yang, X., Rotheram-Fuller, E.J., Hsieh, Y.M., Kintaudi, P.C., Charuvastra, V.C., \& Ling, W. (2003) Randomized placebo-controlled trial of baclofen for cocaine dependence: 
preliminary effects for individuals with chronic patterns of cocaine use. J. Clin. Psychiatry, 64, 1440-1448.

Slattery, D. a, Markou, A., Froestl, W., \& Cryan, J.F. (2005) The GABAB receptor-positive modulator GS39783 and the GABAB receptor agonist baclofen attenuate the rewardfacilitating effects of cocaine: intracranial self-stimulation studies in the rat.

Neuropsychopharmacology, 30, 2065-2072.

Smolders, I., De Klippel, N., Sarre, S., Ebinger, G., \& Michotte, Y. (1995) Tonic GABA-ergic modulation of striatal dopamine release studied by in vivo microdialysis in the freely moving rat. Eur. J. Pharmacol., 284, 83-91.

Sugam, J. a, Day, J.J., Wightman, R.M., \& Carelli, R.M. (2012) Phasic nucleus accumbens dopamine encodes risk-based decision-making behavior. Biol. Psychiatry, 71, 199-205.

Tepper, J.M., Martin, L.P., \& Anderson, D.R. (1995) GABAA receptor-mediated inhibition of rat substantia nigra dopaminergic neurons by pars reticulata projection neurons. $J$. Neurosci., 15, 3092-3103.

Tyacke, R.J., Lingford-Hughes, A., Reed, L.J., \& Nutt, D.J. (2010) GABAB receptors in addiction and its treatment. Adv. Pharmacol., 58, 373-396.

Uchimura, N. \& North, R.A. (1991) Baclofen and adenosine inhibit synaptic potentials mediated by gamma-aminobutyric acid and glutamate release in rat nucleus accumbens. $J$. Pharmacol. Exp. Ther., 258, 663-668. 
Vlachou, S. \& Markou, A. (2010) GABAB receptors in reward processes. Adv. Pharmacol., 58, 315-371.

Wightman, R.M., Amatore, C., Engstrom, R.C., Hale, P.D., Kristensen, E.W., Kuhr, W.G., \& May, L.J. (1988) Real-time characterization of dopamine overflow and uptake in the rat striatum. Neuroscience, 25, 513-523.

Wightman, R.M. \& Zimmerman, J.B. (1990) Control of dopamine extracellular concentration in rat striatum by impulse flow and uptake. Brain Res. Brain Res. Rev., 15, 135-144.

Wydra, K., Golembiowska, K., Zaniewska, M., Kamińska, K., Ferraro, L., Fuxe, K., \& Filip, M. (2013) Accumbal and pallidal dopamine, glutamate and GABA overflow during cocaine self-administration and its extinction in rats. Addict. Biol., 18, 307-324.

Xi, Z.-X., Ramamoorthy, S., Shen, H., Lake, R., Samuvel, D.J., \& Kalivas, P.W. (2003) GABA transmission in the nucleus accumbens is altered after withdrawal from repeated cocaine. $J$. Neurosci., 23, 3498-3505.

Yorgason, J.T., España, R. a, \& Jones, S.R. (2011) Demon voltammetry and analysis software: analysis of cocaine-induced alterations in dopamine signaling using multiple kinetic measures. J. Neurosci. Methods, 202, 158-164.

Zhang, H. \& Sulzer, D. (2004) Frequency-dependent modulation of dopamine release by nicotine. Nat. Neurosci., 7, 581-582.

Zhang, H. \& Sulzer, D. (2012) Regulation of striatal dopamine release by presynaptic auto- and heteroreceptors. Basal Ganglia, 2, 5-13. 
Zhang, L., Doyon, W.M., Clark, J.J., Phillips, P.E.M., \& Dani, J.A. (2009a) Controls of tonic and phasic dopamine transmission in the dorsal and ventral striatum. Mol. Pharmacol., 76, 396404.

Zhang, T., Zhang, L., Liang, Y., Siapas, A.G., Zhou, F.-M., \& Dani, J. a (2009b) Dopamine signaling differences in the nucleus accumbens and dorsal striatum exploited by nicotine. $J$. Neurosci., 29, 4035-4043.

Zhou, F.M., Liang, Y., \& Dani, J. a (2001) Endogenous nicotinic cholinergic activity regulates dopamine release in the striatum. Nat. Neurosci., 4, 1224-1229. 


\section{Figure legends}

Figure 1. Baclofen suppresses DA release evoked by a single pulse stimulus. A) Baclofen $(100 \mu \mathrm{M}, 10 \mathrm{~min}, \mathrm{n}=9$ recordings from 3 animals $=9 / 3$, filled circles $)$ suppresses evoked DA release in NAc core slices. This effect is blocked when baclofen is administered with the GABA antagonist, CGP 52432 ( $n=6 / 3$, open squares). B) Bar graph demonstrating DA release before (open bar) during (light shaded bar) and after washout of baclofen (dark shaded bar). C) Bar graph demonstrating DA release before (open bar), during CGP 52432 application alone (light shaded bar) or during co-application of CGP 52432 with baclofen (dark shaded bar). D) Example concentration vs. time plots with corresponding voltammograms depicting the concentration of DA released at baseline (black line) or after a 10 minute application of $100 \mu \mathrm{M}$ baclofen (grey line). E) Concentration response curve for baclofen $(0.3-300 \mu \mathrm{M}, \mathrm{n}=3-11)$. Bars represent mean \pm S.E.M. $* * *=p<0.001$.

Figure 2. Baclofen-mediated suppression of evoked DA release does not desensitize over time. A) Baclofen-mediated suppression of evoked DA release does not desensitize with 1 hour exposure to baclofen $(100 \mu \mathrm{M})$. B) Example concentration vs. time plots of evoked DA release in the absence (black line), or in the presence of baclofen at 10 (light grey line) or 60 min (dark grey line). C) Bar graph of the concentration of evoked DA release in the absence (open bar) or presence of baclofen at 10 (light shaded bar) or 60 min (dark shaded bar) $(n=8 / 3)$. D) The averaged time constant of decay (tau) in the absence (open bar) or presence of baclofen at 10 or $60 \min (n=8 / 3)$. Bars represent mean \pm S.E.M. $* *=p<0.01$

Figure 3. Baclofen-mediated suppression of evoked DA release does not require cholinergic input. A) Example concentration vs. time plots before (black line, filled circles) and after (grey 
line, open circles) baclofen application in artificial cerebral spinal fluid (ACSF) (left panel) or co-applied mecamylamine (right). An example trace from before application of mecamylamine is shown with open diamonds. B) Bar graphs demonstrating the effect of $100 \mu \mathrm{M}$ baclofen (shaded bars) compared to baseline (open bars) on evoked DA release in the absence (left; $n=7 / 3$ ) or presence of $100 \mu \mathrm{M}$ mecamylamine (right: $\mathrm{n}=7 / 3$ ). Data is expressed as mean \pm S.E.M. $* * *=p$ $<0.001 . * *=\mathrm{p}<0.01$.

Figure 4. Baclofen inhibits DA in a frequency dependent manner. A) The time course of baclofen $(100 \mu \mathrm{M})$ on DA release electrically evoked with a 5 pulse $10 \mathrm{~Hz}$ (filled circles, $\mathrm{n}=$ 9/3) or a 5 pulse $100 \mathrm{~Hz}$ stimulus (open squares; $n=9 / 4$ ). B) Example concentration vs. time plots depicting DA release evoked with 5 pulse stimuli at $10 \mathrm{~Hz}$ (left) or $100 \mathrm{~Hz}$ (right) in the absence (black line) or presence (grey line) of $100 \mu \mathrm{M}$ baclofen (10 min). C) Bar graph demonstrating the maximal effect of baclofen $(10 \mathrm{~min}, 100 \mu \mathrm{M})$ on DA release evoked by differing stimulation protocols $(\mathrm{n}=9 / 3-4$ for all bars). Data is expressed as mean \pm S.E.M, $* *=$ $\mathrm{p}<0.01, * * *=\mathrm{p}<0.001$

Figure 5. Baclofen increases the paired pulse ratio of DA release. A) Example concentration vs. time plots depicting DA release evoked by a single pulse stimulus (P1) or a 2 pulse $100 \mathrm{~Hz}$ stimulus (P1+P2, black lines) and the calculated DA release attributable to the $2^{\text {nd }}$ pulse of the 2 pulse stimulus (P2, grey lines) under baseline conditions or in the presence of $100 \mu \mathrm{M}$ baclofen. Inset, diagram of the stimulation protocols used. B) As in A) but with $300 \mathrm{nM}$ quinpirole. C) Peak DA release attributable to P2 divided by peak DA release evoked by P1 before (open bar) and during (shaded bar) $100 \mu \mathrm{M}$ baclofen $(\mathrm{n}=11 / 4)$ or $300 \mathrm{nM}$ quinpirole application $(\mathrm{n}=7 / 3)$. Bars represent mean \pm S.E.M, $*=p<0.05, * *=p<0.01 . * * *=p<0.001$ 


\section{Figure 6. Baclofen-mediated suppression of DA release persists with sensitizing cocaine}

treatment. A) Distance travelled by mice during 30 minutes immediately following i.p. cocaine $(15 \mathrm{mg} / \mathrm{kg}$; shaded bars) or saline $(0.9 \%$; open bar) injections $(\mathrm{n}=6)$. B) Example concentration vs. time plots of evoked DA in the presence (grey lines) or absence (black line) of $100 \mu \mathrm{M}$ baclofen after saline (left panel) or cocaine (right panel) treatment. C) Effect of $100 \mu \mathrm{M}$ baclofen (10 min) on DA release evoked by a single pulse stimulus after chronic saline (open bars) or cocaine treatment (shaded bars) at 24 hours or $10-12$ days withdrawal $(n=4-7 / 3)$. C) D) Time course of CGP 52432 on single pulse evoked DA release from mice withdrawn from chronic cocaine treatment $(10-12$ days, $n=4 / 3)$. E) Bar graph compares maximal evoked DA release before (open bar) as well as 10 (light shaded bar) and 30 min (dark shaded bar) after CGP 52432 application. Data is expressed as mean \pm S.E.M, $*=p<0.05$. 
A

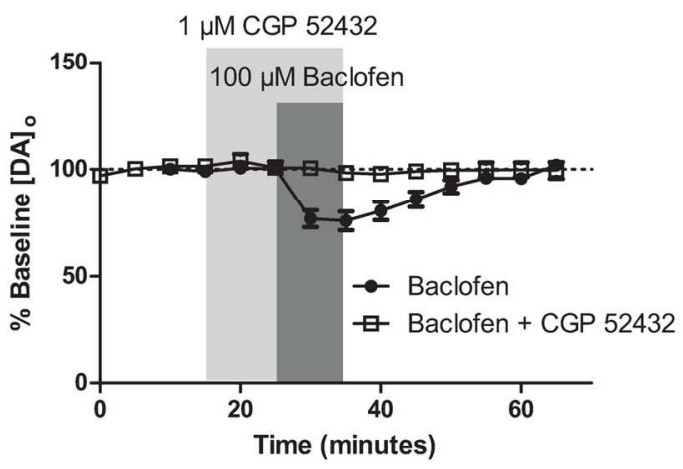

D

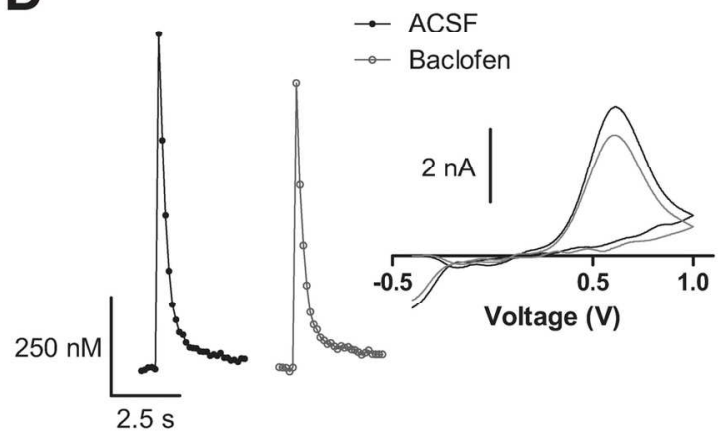

B

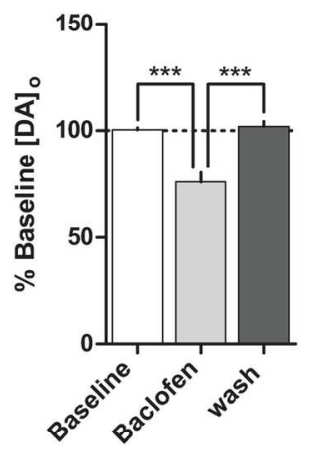

C
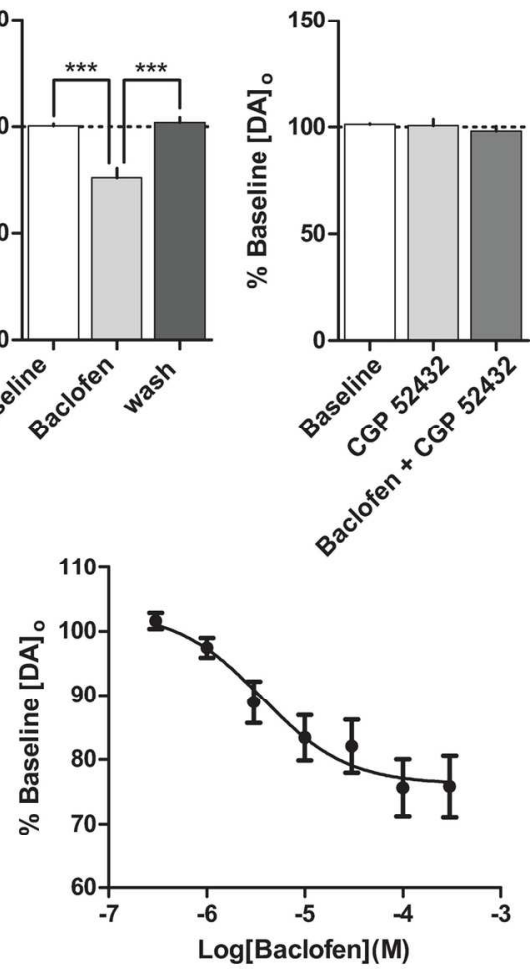

Figure 1. Baclofen suppresses DA release evoked by a single pulse stimulus. A) Baclofen (100 $\mu \mathrm{M}, 10$ min, $\mathrm{n}=9$ recordings from 3 animals $=9 / 3$, filled circles) suppresses evoked DA release in NAc core slices. This effect is blocked when baclofen is administered with the GABAB antagonist, CGP 52432 ( $n=6 / 3$, open squares). B) Bar graph demonstrating DA release before (open bar) during (light shaded bar) and after washout of baclofen (dark shaded bar). C) Bar graph demonstrating DA release before (open bar), during CGP 52432 application alone (light shaded bar) or during co-application of CGP 52432 with baclofen (dark shaded bar). D) Example concentration vs. time plots with corresponding voltammograms depicting the concentration of DA released at baseline (black line) or after a 10 minute application of $100 \mu \mathrm{M}$ baclofen (grey line). E) Concentration response curve for baclofen $(0.3-300 \mu \mathrm{M}, \mathrm{n}=3-11)$. Bars represent mean \pm S.E.M. $* * *=\mathrm{p}<0.001$.

$150 \times 124 \mathrm{~mm}(300 \times 300 \mathrm{DPI})$ 


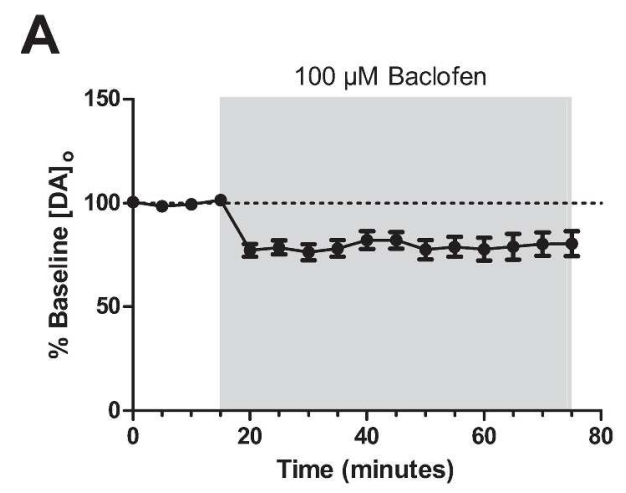

B
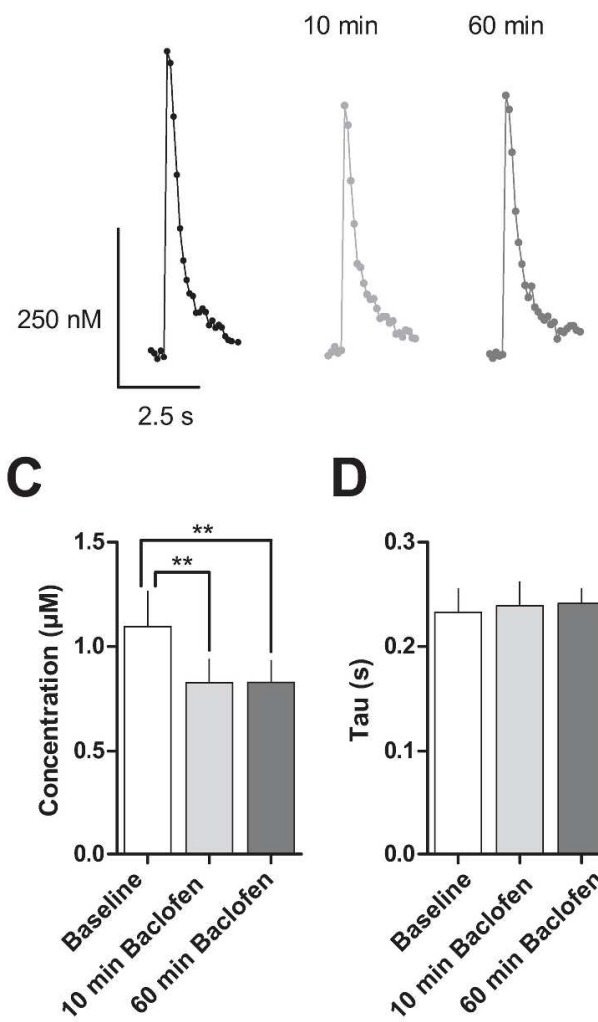

D

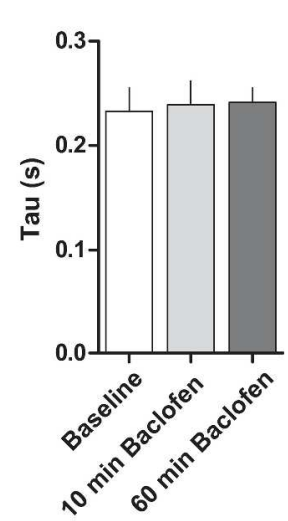

Figure 2. Baclofen-mediated suppression of evoked DA release does not desensitize over time. A) Baclofenmediated suppression of evoked DA release does not desensitize with 1 hour exposure to baclofen $(100 \mu \mathrm{M})$. B) Example concentration vs. time plots of evoked DA release in the absence (black line), or in the presence of baclofen at 10 (light grey line) or 60 min (dark grey line). C) Bar graph of the concentration of evoked DA release in the absence (open bar) or presence of baclofen at 10 (light shaded bar) or 60 min (dark shaded bar) $(n=8 / 3)$. D) The averaged time constant of decay (tau) in the absence (open bar) or presence of baclofen at 10 or 60 min $(n=8 / 3)$. Bars represent mean \pm S.E.M. $* *=p<0.01$.

$222 \times 572 \mathrm{~mm}(300 \times 300 \mathrm{DPI})$ 
A

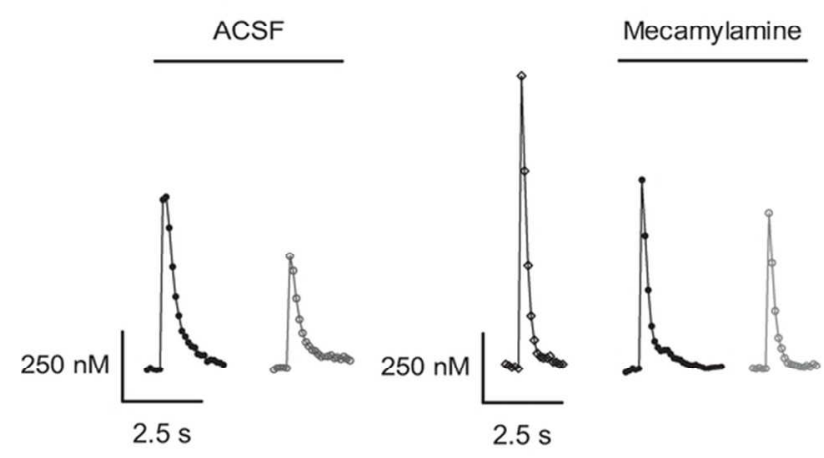

B

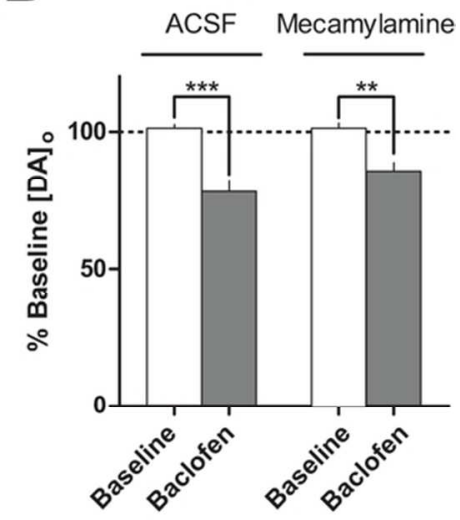

Figure 3. Baclofen-mediated suppression of evoked DA release does not require cholinergic input. A) Example concentration vs. time plots before (black line, filled circles) and after (grey line, open circles) baclofen application in artificial cerebral spinal fluid (ACSF) (left panel) or co-applied mecamylamine (right). An example trace from before application of mecamylamine is shown with open diamonds. B) Bar graphs demonstrating the effect of $100 \mu \mathrm{M}$ baclofen (shaded bars) compared to baseline (open bars) on evoked DA release in the absence (left; $n=7 / 3$ ) or presence of $100 \mu \mathrm{M}$ mecamylamine (right: $n=7 / 3$ ). Data is expressed as mean \pm S.E.M. ${ }^{* * *}=\mathrm{p}<0.001 .{ }^{* *}=\mathrm{p}<0.01$.

$76 \times 33 \mathrm{~mm}(300 \times 300 \mathrm{DPI})$ 
A

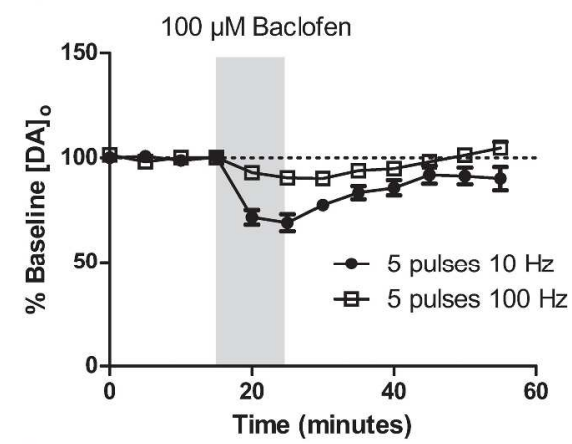

B
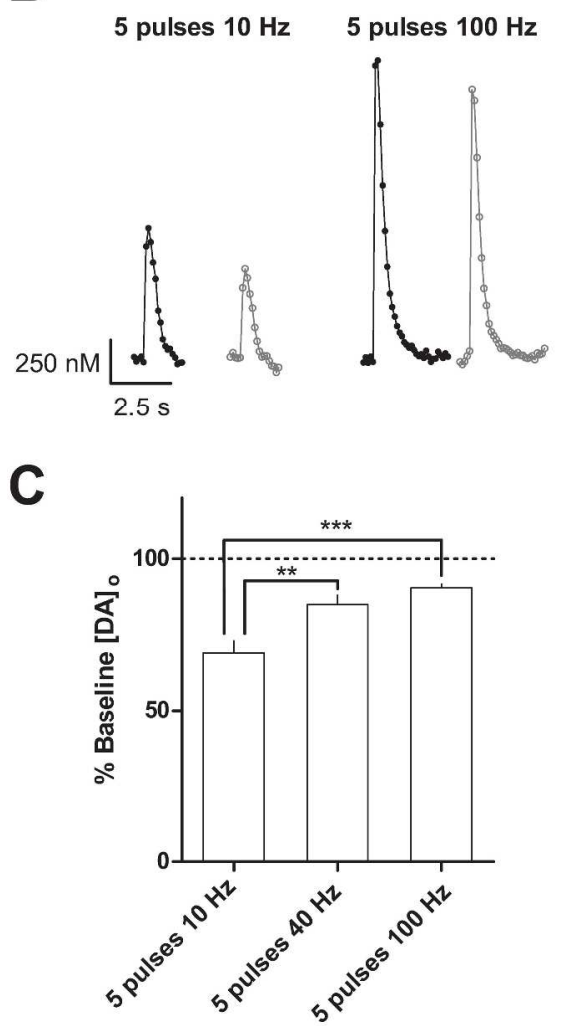

Figure 4. Baclofen inhibits DA in a frequency dependent manner. A) The time course of baclofen $(100 \mu \mathrm{M})$ on DA release electrically evoked with a 5 pulse $10 \mathrm{~Hz}$ (filled circles, $n=9 / 3$ ) or a 5 pulse $100 \mathrm{~Hz}$ stimulus (open squares; $n=9 / 4)$. B) Example concentration vs. time plots depicting DA release evoked with 5 pulse stimuli at $10 \mathrm{~Hz}$ (left) or $100 \mathrm{~Hz}$ (right) in the absence (black line) or presence (grey line) of $100 \mu \mathrm{M}$ baclofen $(10 \mathrm{~min})$. C) Bar graph demonstrating the maximal effect of baclofen (10 min, $100 \mu \mathrm{M})$ on DA release evoked by differing stimulation protocols ( $n=9 / 3-4$ for all bars). Data is expressed as mean \pm S.E.M, $* *=p<0.01, * * *=p<0.001$.

$222 \times 621 \mathrm{~mm}(300 \times 300 \mathrm{DPI})$ 

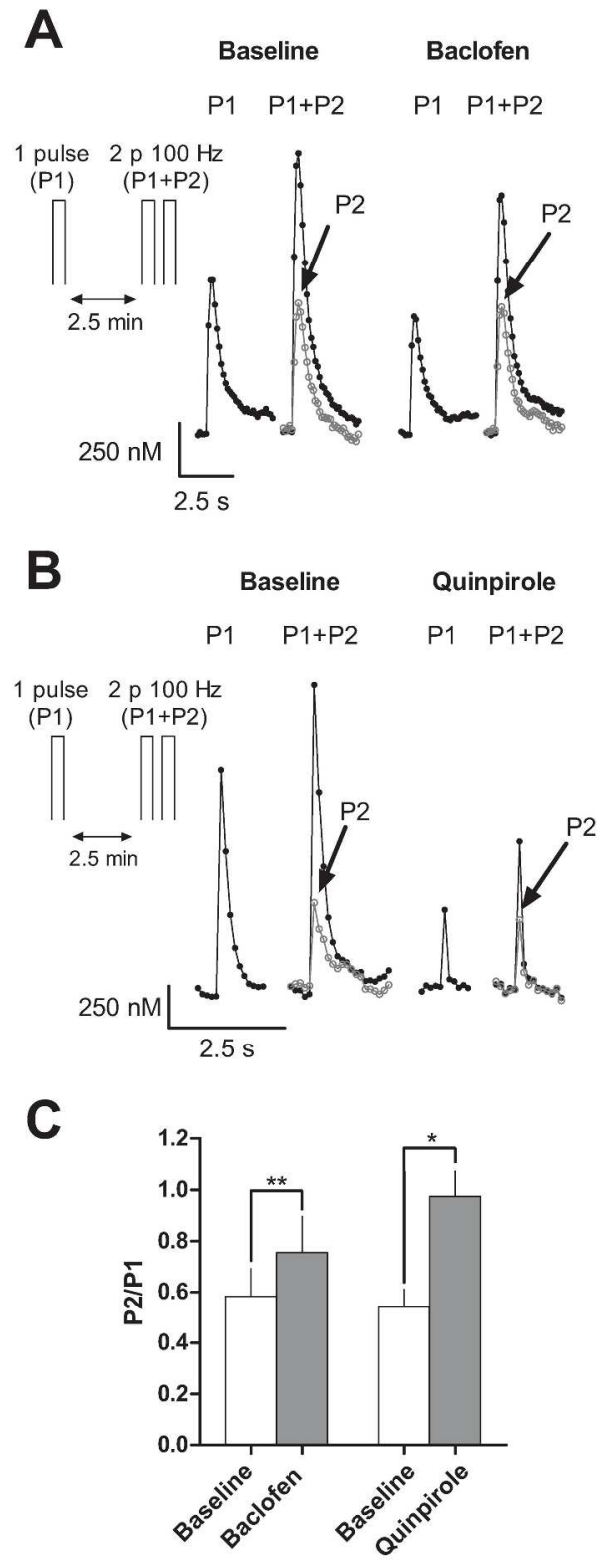

Figure 5. Baclofen increases the paired pulse ratio of DA release. A) Example concentration vs. time plots depicting DA release evoked by a single pulse stimulus (P1) or a 2 pulse $100 \mathrm{~Hz}$ stimulus ( 1 1+P2, black lines) and the calculated DA release attributable to the 2nd pulse of the 2 pulse stimulus (P2, grey lines) under baseline conditions or in the presence of $100 \mu \mathrm{M}$ baclofen. Inset, diagram of the stimulation protocols used. B) As in A) but with $300 \mathrm{nM}$ quinpirole. C) Peak DA release attributable to P2 divided by peak DA release evoked by P1 before (open bar) and during (shaded bar) $100 \mu \mathrm{M}$ baclofen $(n=11 / 4)$ or $300 \mathrm{nM}$ quinpirole application $(n=7 / 3)$. Bars represent mean \pm S.E.M, $*=p<0.05, * *=p<0.01 . * * *=p$ $<0.001$.

$226 \times 604 \mathrm{~mm}(300 \times 300$ DPI $)$ 
A

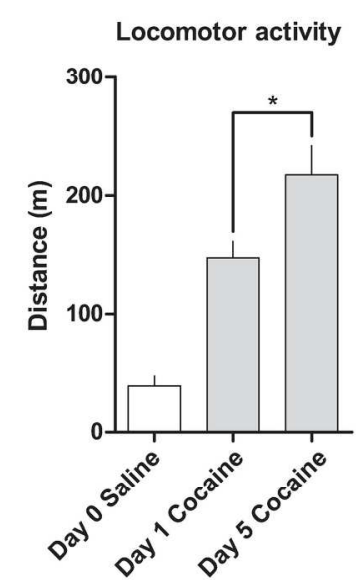

C

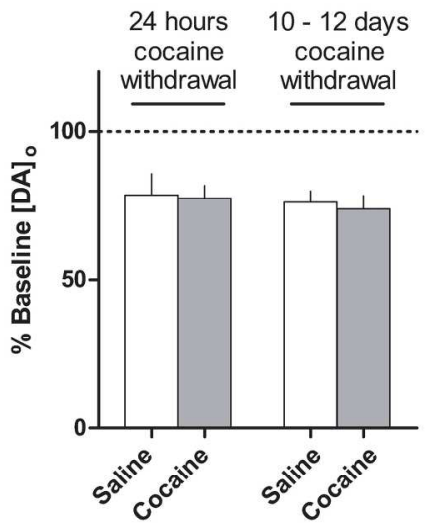

B

\author{
Saline control (24 hours)
}

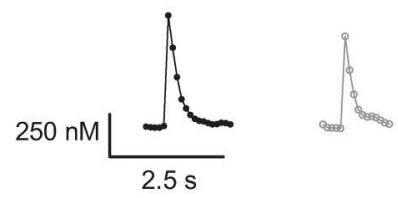

Saline control (10 - 12 days)
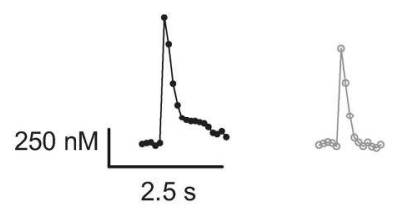

$250 \mathrm{nM}$

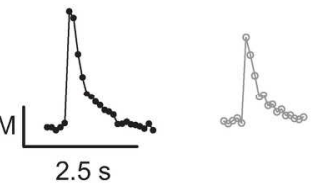

D

E
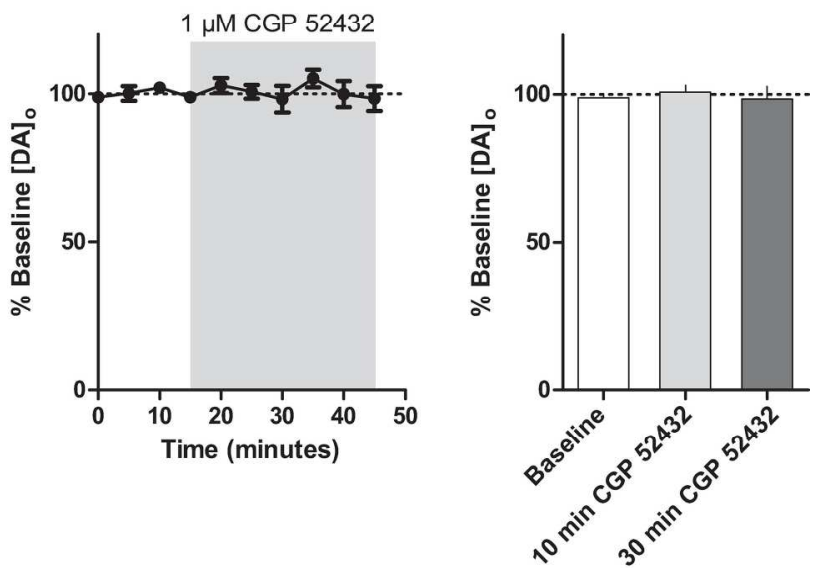

Figure 6. Baclofen-mediated suppression of DA release persists with sensitizing cocaine treatment. A) Distance travelled by mice during 30 minutes immediately following i.p. cocaine (15 mg/kg; shaded bars) or saline $(0.9 \%$; open bar) injections $(n=6)$. B) Example concentration vs. time plots of evoked DA in the presence (grey lines) or absence (black line) of $100 \mu \mathrm{M}$ baclofen after saline (left panel) or cocaine (right panel) treatment. C) Effect of $100 \mu \mathrm{M}$ baclofen (10 min) on DA release evoked by a single pulse stimulus after chronic saline (open bars) or cocaine treatment (shaded bars) at 24 hours or $10-12$ days withdrawal $(n=4-7 / 3)$. C) D) Time course of CGP 52432 on single pulse evoked DA release from mice withdrawn from chronic cocaine treatment (10 - 12 days, $n=4 / 3)$. E) Bar graph compares maximal evoked DA release before (open bar) as well as 10 (light shaded bar) and 30 min (dark shaded bar) after CGP 52432 application. Data is expressed as mean \pm S.E.M, $*=p<0.05$. $196 \times 207 \mathrm{~mm}(300 \times 300$ DPI $)$ 
Baclofen, an agonist of the $\mathrm{GABA}_{\mathrm{B}}$ receptor, decreases the probability of dopamine release in the nucleus accumbens core. This effect was due to a direct action on $\mathrm{GABA}_{\mathrm{B}}$ receptors located on dopamine neuron terminals. Baclofen's effect on dopamine release was not reduced after sensitising cocaine treatment suggesting a potential mechanism for baclofen's reported usefulness in addiction pharmacotherapy. 

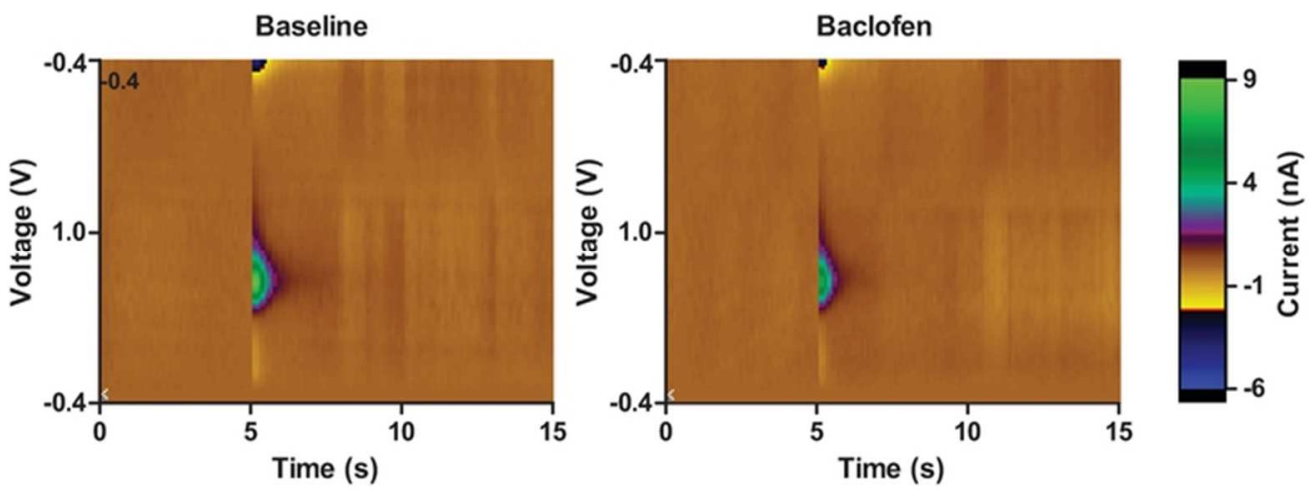

$61 \times 22 \mathrm{~mm}(300 \times 300$ DPI $)$ 